\title{
Implementasi Model Pembelajaran Patriot untuk Mengembangkan Kemampuan Mengelola Usaha Mahasiswa
}

\author{
Naswan Suharsono \\ Universitas Negeri Malang, Malang - Indonesia
}

\section{A R T I C L E I N F O}

Article history:

Received June, 232021

Received in revised form June, 262021

Accepted June, 272021

Available online June, 28 2021

Kata Kunci:

E-learning, kemampuan mengelola usaha, mitra kerja, pembelajaran digital, pola pembelajaran.

Keywords: Ability to manage business, digital learning, E-learning, learning patterns, partners.

\section{A B S T R A K}

Penelitian ini dilakukan untuk mengeksplorasi adanya pola-pola pembelajaran kewirausahaan yang bisa dimanfaatkan untuk mengembangkan kemampuan mengelola usaha para mahasiswa melalui implementasi model PATROT pasca pandemik covid-19. Kegiatan lapangan didasarkan pada pemikiran bahwa peningkatan kemampuan berinovasi secara kreatif, keberanian menghadapi resiko, dan mengubah tantangan menjadi peluang merupakan karakter dasar pembentuk perilaku berkarya wirausaha lulusan perguruan tinggi. Penelitian eksploratoris ini dilakukan di 5 kelas mahasiswa FE Undiksha Singaraja, dan 5 kelas partner mahasiswa FE UM offering 2020 yang mengambil program kuliah Kewirausahaan. Data didapatkan melalui telaah dokumen dan angket balikan mahasiswa tentang efektivitas pembelajaran yang dianalisis deskriptif sesuai karakteristik informasi dan analisis isi sesuai muatan pesannya. Hasil penelitian menunjukkan bahwa, ada lima komponen kegiatan pembelajaran yang bisa diintegrasikan atau dikombinasikan untuk mengembangkan kemampuan melakukan tindakan usaha meliputi pencarian informasi online, interaksi pembelajaran (sinkron vs asinkron), latihan kerja (kelompok vs mandiri), asesmen (proses vs hasil), serta balikan dan tindak lanjut. Hasil penelitian menunjukkan bahwa kemampuan mengelola usaha dapat ditingkatkan melalui mekanisme kerjasama dalam kerja-kelompok, bersama dosen pembimbing dan mitra kerja proyeknya. Temuan penelitian ini hendaknya dilanjutkan dengan menguji tingkat keefektivan pola-pola pembelajaran dan skenario mengintegrasikan kegiatan kerja online, penugasan laboratorium KWU dan kemitra usahaan dengan praktisi.

\section{A B S T R A C T}

This study was conducted to explore the existence of entrepreneurial learning patterns that can be used to develop students' business management skills through the implementation of the PATROT model after the COVID-19 pandemic. Field activities are based on the idea that increasing the ability to innovate creatively, the courage to face risks, and turning challenges into opportunities are the basic characteristics that shape the entrepreneurial behavior of college graduates. This exploratory research was conducted in 5 classes of FE Undiksha Singaraja students, and 5 classes of partner students of FE UM offering 2020 who took the Entrepreneurship course. Data were obtained through document review and student questionnaires about the effectiveness of learning which were analyzed descriptively according to the characteristics of the information and content analysis according to the message content. The results of the study indicate that there are five components of learning activities that can be integrated or combined to develop the ability to take business actions such as online information search, learning interaction (synchronous vs asynchronous), job training (group vs independent), assessment (process vs outcome), and feedback and follow-up. The results of the study indicate that the ability to manage a business can be improved through a cooperative mechanism in group work, with the supervisor and project partners. The findings of this study should be continued by testing the effectiveness of learning patterns and scenarios for integrating online work activities, KWU laboratory assignments and business partnerships with practitioners. 


\section{Pendahuluan}

Munculnya Coronavirus disease (Covid-19) di era revolusi industri 4.0 telah membawa perubahan pola pikir, etos kerja dan tindakan para pelaku usaha. Tindakan profesi wirausaha merupakan salah satu pekerjaan yang bisa ditumbuh kembangkan dengan jalan memasukkan ajaran nilai dan prinsip dasar kewirausahaan dalam kurikulum dan pembinaan kemahasiswaan di perguruan tinggi. Program-program itu kini makin diperluas dengan sejumlah kegiatan perkuliahan dan program pelatihan mahasiswa menjadi wirausaha sehingga setiap perguruan tinggi di Indonesia umumnya mengambil peran menjadi pusat pengembangan kewirausahaan bagi masyarakat dan bangsanya. Namun, kenyataannya usaha itu tidaklah mudah diwujudkan.

Kewirausahaan sebagai bagian dari dharma bidang pendidikan diharapkan bisa berkontribusi pada peningkatan niat (intention) berwirausaha dan etos kerja untuk mewujudkannya dengan untuk memperluas pemahaman tentang bagaimana wirausaha bisa diperkuat melalui pengayaan pengalaman (experiential) dan kemampuan menangkap peluang berwirausaha secara terintegrasi, sebagaimana tercermin dalam pola-pola pembelajaran yang dikembangkan para dosen di dalam menjalankan dharma pendidikannya. Sebagaimana direkomendasikan Direktorat Belmawa (2018), solusi yang bisa ditempuh adalah dilakukannya pengembangan strategi dan kebijakan tertentu di setiap perguruan tinggi untuk mewujudkan entrepreutical campus yang dapat meningkatkan kompetensi kerja dan produktivitas bagi mahasiswanya. Oleh karena itu diperlukan kerja bersama antar Perguruam Tinggi (PT) untuk mengembangkan model-model pembelajaran kewirausahaan dengan beragam pola kegiatannya untuk mahasiswa. Masalah yang timbul selama ini bisa terjadi karena tradisi perkuliahan di PT pada umumnya lebih ditekankan pada penanaman konsep, prinsip, aturan-hukum dan teori, sementara pengenalan terhadap keadaan riel di lapangan dan kemampuan bertindak cepat mengatasi masalah belum bisa dioptimalkan.

Pengetahuan kewirausahaan sebagian besar telah diupayakan dari perspektif pembelajaran kewirausahaan. Dalam hubungan ini, pendidikan kewirausahaan terdiri dari "program pedagogis terintegrasi proses pendidikan keilmuan, karakter, dan keterampilan kewirausahaan. Ini memiliki sejarah yang relatif panjang dan telah berkembang menjadi fenomena yang luas (Garba dan Abubakar, 2019). Program pendidikan kewirausahaan itu sendiri telah berkembang secara signifikan di AS dan Eropa selama beberapa dekade terakhir. Perluasan tren penelitian pembelajaran kewirausahaan menunjukkan bahwa pembelajaran kewirausahaan dapat bermanfaat bagi para siswa dalam perolehan pengetahuan dan keterampilan serta dalam meningkatkan niat (berwirausaha (Nabi et al., 2017 ). Temuan Handayati et.al., 2020) juga menunjukkan bahwa pembelajaran kewirausahaan secara positif berpengaruh terhadap pola pikir (maindset) dan niat berwirausaha para siswa SMK di Indonesia. Dengan demikian dapat dijelaskan bahwa secara teoretik, pola pikir bisa memediasi adanya hubungan antara pembelajaran kewirausahaan dan niat berwirausaha.

Namun, niat saja tidaklah cukup, kecuali bisa diwujudkan dalam kehidupan dunia usaha yang nyata. Oleh karena itu, mahasiswa harus mendapatkan pengalaman belajar secara terintegrasi dari pengenalan ajaran nilai, penguasaan teori, dan orientasi lapangan yang cukup, sampai akhirnya pada tindakan profesi wirausaha sejati (Suharsono, 2004, Suharsono dan Parma 2020). Penyelenggaraan pembelajaran itu sendiri harus terintegrasi, dari teori ke aplikasi (Suharsono, 2018), secara terintegtasi dapatlah dijelaskan bahwa pembelajaran kewirausahaan menjadi sangat penting baik pada tingkat makro maupun mikro.

Untuk mengetahui dampak dari pengetahuan kewirausahaan terhadap keberhasilan program pembelajaran kewirausahaan, sebagian besar makalah menekankan bahwa pembelajaran kewirausahaan secara langsung atau tidak langsung berkontribusi untuk meningkatkan niat berwirausaha (Zainuddin dan Ismail, 2011, Suharsono, 2018). Survei longitudinal Roxas (2014) terhadap 245 mahasiswa di Universitas Filipina mengamati efek langsung dan tidak langsung dari pengetahuan terhadap niat wirausaha seseorang meningkat melalui program pendidikan kewirausahaan yang menyoroti pentingnya pengetahuan yang muncul bagi seseorang. Kepercayaan diri dan kecenderungan sikap terhadap kewirausahaan. Selain itu, temuan Malebana (2017) menunjukkan adanya hubungan yang signifikan antara pengetahuan tentang kewirausahaan dan niat berwirausaha mahasiswa di Afrika. Adapun implementasi model-model pembelajaran kewirausahaan dapat berpotensi untuk membangun jembatan bagi kegiatan kewirausahaan yang inovatif seperti konsultan dalam transfer teknologi atau untuk menerapkan mekanisme memperkuat perusahaan (Ianioglo dan Polajeva, 2017) dalam masyarakat yang terus berubah.

Pengetahuan Kewirausahaan, teori pembelajaran pengalaman, dan teori pembelajaran eksperiensial mendefinisikan pembelajaran sebagai proses di mana pengetahuan diciptakan melalui transformasi pengalaman. Pengetahuan dihasilkan dari kombinasi pengalaman menggenggam dan mentransformasikan. 
Teori pembelajaran eksperiensial Kolb dibangun di atas karya awal pembelajaran dan pengembangan manusia yang dilakukan oleh banyak sarjana terkenal. Teori pembelajaran eksperiensial Kolb adalah filosofi pendidikan berdasarkan "teori pengalaman. Sementara pendidikan tradisional memiliki sedikit kebutuhan akan teori karena praktik ditentukan oleh tradisi, pendekatan pengalaman baru terhadap pendidikan membutuhkan teori pengalaman yang kokoh untuk memandu pelaksanaan dari teori ke aplikasi (Alqot, 2021).

Pembelajaran eksperiensial atau pembelajaran aktif, pembelajaran interaktif atau "belajar sambil melakukan" telah membuahkan hasil yang positif. Sebagian besar ahli setuju bahwa ketika siswa berperan aktif dalam proses pembelajaran maka pembelajaran siswa akan lebih optimal (Garba dan Abubakar, 2019).

\section{Metode}

Penelitian ini menggunakan rancangan penelitian survey deskriptif dengan paradigma konstruktivisme untuk pengembangan komponen-komponen perangkat pendukung pembelajaran. Secara keseluruhan, kegiatan penelitian mengikuti tiga fase untuk mewujudkannya. Ketiga fase itu adalah pembuatan perangkat pembelajaran KWU, fase pelaksanaan di kelas, dan fase evaluasi proses dan hasil pembelajaran. Adapun para pihak yang terlibat dalam kegiatan ini adalah mereka yang menjadi pelaku kegiatan itu sendiri yaitu pihak dosen dan mahasiswa beserta laboratorium kewirausahaan dan praktisi dunia usaha di lapangan.

Kegiatan penelitian ini dilakukan di 5 kelas mahasiswa FE Undiksha Singaraja dan 5 kelas FEB UM yang mengambil program kuliah Kewirausahaan sesuai tuntutan kurikulum. Komposisi peserta adalah mahasiswa program S-1 yang pada tahapan pelaksanaannya diampu oleh 10 dosen pengampu matakuliah ditambah praktisi di obyek lokasi kegiatan lapangan atau pasar yang diciptakan bersama dosen dan mahasiswa berdasarkan proyek berpraktek wirausaha.

Ada lima tahapan yang telah dilalui, dimulai dari kegiatan kajian hasil-hasil penelitian terdahulu yang relevan dengan produk yang akan direkayasa, dilanjutkan dengan pembuatan skenario kegiatan pembelajaran.Tahapan selanjutnya adalah implementasi model PATRIOT dalam situasi dan kondisi riel di kelas. Kelas yang dimaksud adalah perkuliahan di perguruan tinggi tempat berlangsungnya kegiatan pendidikan dan pembelajaran di kelas online yang didukung dengan prasarana dan sarana belajar yang memadai.

Data yang didapatkan dianalisis dengan teknik deskriptif, analisis varian satu jalur, dan analisis eSWOT sesuai keperluan untuk menggali data dan informasi sebagai masukan bagi penyempurnaan produk akhir. Demikian juga halnya dengan penilaian produk dari sisi peningkatan nilai tambah dengan masuknya konsep blended learning dalam ranah pengembangan teknologi pembelajaran online lintas program studi di lingkungan FE Undiksha dan FE Universitas Negeri Malang.

\section{Hasil dan pembahasan Hasil Penelitian}

Ada tiga pertanyaan penelitian yang diajukan, yaitu Pertama, apakah variasi pola pembelajaran kewirausahaan dengan spesifikasi, target sasaran calon-calon kelompok wirausaha muda dapat mencapai standar kompetensi tingkat tinggi? Kedua, Apakah variasi sintaks pembelajaran dengan fokus pada uji kompetensi tingkat tinggi, dari teoretik ke aplikasi di lapangan dapat meningkatkan kemampuan mengelola usaha. Ketiga, apakah ada perbedaan hasil belajar antar belajar kelas-kelas dengan variasi pola pembelajaran kewirausahaan yang diterapkan di lapangan?

Pertama, hasil analisis isi komponen produk menunjukkan adanya perbedaan variasi pola kombnasi antar kelompok partisipan dari lima kelompok sampel yang mewakili uji-lapangan. Pada kelompok MK1, partisipasi mahasiswa terbawa oleh suasana belajar dan pembelaran kelas non-klasikal, sehinga motivasi belajar mahasiswa lebih dikarenakan adanya keuntungan lain, yaitu dikaitkannya kegiatan ini dengan tugas penyusunan proposal Program Kreativitas Mahasiswa bidang Kewirausahaan (PKMK). Namun secara umum, tampilan mahasiswa menjadi semakin mandiri dan intensif keaktivannya pada saat mengerjakan tugas-tugas latihan, khususnya pada saat mengoperasikan program interaktif dalam proses penguasaan PAT di ruang kelas komputer. Dari hasil Uji implementasi pembelajaran dapat diketahui adanya variasi keaktivan belajar mahasiswa selama pembelajaran berlangsung. Pertanyaannya adalah, apakah variasi proses itu juga membawa dampak secara signitikan dengan perbedaan hasil belajar mahasiswa?

Hasil analisis isi variasi komponen pola pembelajaran menunjukkan adanya perbedaan tingkat partisipasi antar kelompok partisipan dari lima kelompok sampel yang mewakili uji-empirik. Perbedaan 
tingkat partisipasi dan keaktivan antar kelompok itu disebabkan adanya perbedaan skenario kegiatan belajar dan intensitas pemanfaatan online dalam proses penguasaan PAT di ruang kelas tatap muka dan di ruang media online.

Kedua, Hasil-hasil analisis statistik tentang perbedaan skor dalam kelompok dan antar kelompok subyek yang diteliti? Sesuai tuntutan skenario pembelajaran, setiap kelompok mahasiswa subyek penelitian, baik pada saat mengikuti presentasi, mengerjakan tugas latihan, tugas mandiri, maupun tugas proyek hasil untuk mengukur hasil akhir tindak belajar. Setiap kelompok subyek sampel berstatus sebagai mahasiswa aktif sehingga hasil belajar ini dapat dikreditkan. Dari hasil analisis statistik deskriptif dapat diketahui adanya variasi hasil belajar pada kelima kelompok mahasiswa. Demikian juga halnya dengan besarnya perbedaan angka mean setiap kelompok kelas. Hasil analisis data empirik ini menunjukkan bahwa, dalam batas-batas yang bisa dideteksi, peserta kuliah memiliki latar belakang pengalaman belajar online relatif hiterogen. Dari Hasil analisis data dapat dilihat adanya penurunan tingkat kesulitan kelompok mahasiswa dalam mengikuti pembelajaran dan akses informasi di jaringan internet. Variasi kecepatan akses ternyata dipengaruhi juga oleh variabel jenis modem layanan internet yang digunakan dan pengalaman mahasiswa dalam melakukan penelusuran laman website.

Dari hasil analisis varian satu jalur dapat diketahui adanya pengaruh yang tidak signifikan dari hasil belajar antar kelompok kelas dengan materi dan kompetensi yang relevan dipelajari pada saat uji-empirik berlangsung. Artinya, sejauh ini memang ada perbedaan kompetensi sesudah mahasiswa mendapatkan Kuliah dengan ketiga pola yang diteliti. Akan tetapi perbedaan antar kelompok bidang studi obyek ujiempirik penelitian pengembangan jiwa wirausaha dan pemanfaatan teknologi informasi mahasiswa tidak signifikan. Hanya saja perlu diperhatikan bahwa angka-angka hasil analisis data dimaksudkan untuk bisa memberikan sumbangan terhadap kegiatan pengembangan pola-pola pembelajaran berikutnya.

Ketiga, dari analisis data dengan teknik beda mean tampak adanya variasi perbedaan yang tidak signifikan skor antar kelompok subyek penelitian dengan taraf signifikansi yang berbeda-beda. Perbedaan itu kemungkinan karena latar belakang pengalaman pendidikan, perbedaan obyek profesi yang digarap, serta kemungkinan adanya pembiasan dalam analisis statistik parametrik, di samping sebab-sebab lainnya. Sebagaimana telah dijelaskan pada latar belakang terdahulu bahwa ada keterkaitan erat antara variabel yang dipilih dengan kondisi riel di lapangan. Adanya perbedaan itu menunjukkan bahwa ada sejumlah variabel eksternal maupun variabel internal yang telah terbentuk sebagai hasil-hasil belajar yang menyenangkan, namun tidak bisa diukur secara pasti. Demikian juga halnya dengan penggabungan skor 5 (lima) kelompok kelas FE Undiksha dan skor 5 (lima) kelompok kelas FEB UM tidak ditemukan adanya perbedaan yang signifikan antar kelompok skor 10 kelas yang diteliti. Pertanyaannya adalah, seberapa besar pengaruh hasil-hasil belajar terdahulu dan kontribusi media pembelajaran terhadap keefektivan proses pembelajaran individu saat mereka belajar sendiri dan saat belajar bersama kelompok kecilnya? Dari hasil wawancara terbuka kepada 20 mahasiswa Undiksha yang tergabung dalam Young Entrepreneur Indonesia (YES) dapat disintesiskan bahwa mengintegrasikan belajar dan bekerja merupakan salah satu wahana berpraktek dan menajamkan fokus ke masa depan.

\section{Pembahasan}

Pengembangan profesi kewirausahaan di lapangan menunjukkan bahwa paparan pembelajaran kewirausahaan dapat bermanfaat bagi mahasiswa dalam perolehan pengetahuan dan keterampilan serta dalam meningkatkan niat dan kiat berwirausaha (Nabi et al., 2017). Oleh karena itu, perlu dilakukan penelitian lanjutan di bidang kewirausahaan agar dapat dilakukan deteksi dan dievaluasi dampak terhadap perubahan pola perilaku usaha melalui program pembelajaran kewirausahaan yang relevan dengan tuntutan zamannya. Demikian juga dalam hal melakukan penelitian implementasi experiential learning dalam proses mencari peluang yang diukur dalam intensi dan aksi dalam kewirausahaan. Demikian juga halnya dengan sumbangan penelitian terhadap perkembangan teori pembelajaran digital dan aplikasinya dalam praktek bertindak wirausaha secara berkelanjutan?

\section{Keterlaksanaan Variasi Pembelajaran KWU di Kelas}

Uji keterlaksanaan pembelajaran dilakukan untuk mengetahui sejauh mana skenario KBM telah berjalan sesuai rancangan yang dipolakan dan bagian mana yang tidak bisa berjalan sesuai nalisis komponen di muka adalah jawabannya. Sintesis yang bisa ditemukan adalah bahwa penguasaan kompetensi harus dilakukan secara bertahap melalui pokok-pokok bahasan dengan bantuan media pembelajaran yang dirancang dan lingkungan profesi yang difokuskan pada penayangan kegiatan dunis profesi dan industri penghasil produk barang dan jasa.

Media yang dirancang untuk meningkatkan penguasaan pengetahuan teoritis (PAT), sedangkan lingkungan profesi untuk meningkatkan kemampuan interkatif dalam upaya mengenali realitas, akses informasik dan obyek-obyek profesi. Adapun kemampuan melakukan tindakan profesi (T) dapat 
diprediksikan dari hasil-hasil latihan menemukan alternatif kemampuan mengelola usaha dengan jalan mengoptimalkan keunggulan (strongness) yang dimiliki, meminimalkan kelemahan (weakness), serta dengan memanfaatkan peluang yang ada, dan kiat pedagogis mengubah ancaman atau hambatan menjadi peluang sukses sebagai wirausaha muda Indonesia.

\section{Variasi Sintaks pola Belajar Mahasiswa KWU}

Dari hasil Uji implementasi pembelajaran dapat diketahui adanya variasi keaktivan belajar mahasiswa selama pembelajaran berlangsung. Pertanyaannya adalah, apakah variasi pola itu juga membawa dampak secara signifikan dengan perbedaan hasil belajar mahasiswa? Jika jawabannya berbeda, apakah perbedaan itu lebih disebabkan perbedaan kemampuan awal atau karena memang ada perubahan ketercapaian standar kompetensi yang diharapkan. Berikut ini tampilan hasil analisis statistik tentang perbedaan hasil belajar dalam kelompok dan antar kelompok subyek yang diteliti?

Sesuai tuntutan skenario pembelajaran, setiap kelompok mahasiswa subyek penelitian, baik pada saat mengikuti presentasi, mengerjakan tugas latihan, tugas mandiri, maupun tugas proyek hasil untuk mengukur hasil akhir tindak belajar. Setiap kelompok subyek sampel berstatus sebagai mahasiswa aktif sehingga hasil belajar ini dapat dikreditkan sebagaimana tercantum di Daftar Peserta dan Nilai Akhir (DPNA). Sebagai gambaran, berikut ini disajikan hasil analisis statistik tentang hasil belajar pada ketiga pola yang divariasikan dalam sintaks pembelajaran.

Pada saat kuliah berlangsung, setiap mahasiswa telah menentukan sendiri obyek studi dan bidang profesi yang ada di lapangan. Pada tahapan awal, mereka melakukan orientasi MK yang terkait dalam program Praktek Berwirausaha. Obyek lokasi kunjungan lapangan diharapkan dapat dipilih dari mereka yang memiliki beberapa jenis kegiatan profesi, sehingga diharapkan setiap mahasiswa memiliki pengalaman kerja yang berbeda-beda tetapi saling berkaitan sebagai satu kesatuan. Adapun hasil belajar terdahuku diidentifikasi sebatas pada hasil tes awal sebagaimana tertuang dalam 10 item tes penguasaan dasar teoretik dan Tugas Pembuatan Rencana Usahayang dapat dipelajari secara mandiri dengan bantuan program tutorial dan referensi yang ada di dalam Paket pembelajaran online terpasang di SSO Undiksha dan SIPEJAR UM.

\section{Hasil Belajar Antar Kelompok Program KWU}

Secara khusus, penelitian Implementasi paket alternatif Program KWU ini sengaja dilakukan dalam latar pembelajaran riel dalam waktu satu semester untuk mengetahui seberapa besar peluang yang ditawarkan kepada mahasiswa dalam program kuliah reguler dapat mengoptimalkan proses pembelajaran dan hasil belajar. Sebagaimana telah dipaparkan pada bagian-bagian terdahulu bahwa pengembangan perangkat program pembelajaran perlu didukung adanya bukti bahwa mahasiswa subyek belajar telah melakukan tindak belajar melalui paket yang sedang diuji implementasi.

Hasil analisis skor perolehan belajar, sebagaimana tampak pada tiga tabel berikut menunjukkan adanya variasi jumlah peserta dan rerata antar skor dari lima kelompok mahasiswa yang dikenai ujiempirik. Pertanyaannya adalah, sejauh mana mahasiswa telah bisa belajar dengan bantuan paket pembelajaran online? Dari hasil analisis statistik deskriptif dapat diketahui adanya variasi hasil belajar pada kelima kelompok mahasiswa. Demikian juga halnya dengan besarnya perbedaan angka mean setiap kelompok kelas. Hasil analisis data empirik ini menunjukkan bahwa peserta kuliah memiliki latar belakang pengalaman belajar online relatif hiterogen, namun perbedaannya tidak signifikan.

\section{Simpulan dan saran}

Penelitian pembelajaran kewirausahaan dengan tiga variasi pola ini menunjukkan bahwa model pembelajaran kewirausahaan yang terintegrasi dan berkelanjutan dapat bermanfaat bagi mahasiswa dalam meningkatkan perolehan pengetahuan dan keterampilan serta dalam meningkatkan kemampuan mengelola usahanya. Komponen pembelajaran yang diimplememtasikan ada lima, yaitu: pengenalan ajaran nilai dasar profesi wirausaha, penguasaan PAT, orientasi lapangan, pengenalan obyek udaha, dan Oleh karena itu, perlu dilakukan penelitian lanjutan di bidang kewirausahaan agar dapat dilakukan deteksi dan dievaluasi dampak terhadap perubahan pola-pola perilaku usaha melalui program pembelajaran kewirausahaan yang relevan dengan tuntutan zamannya. Demikian juga dalam hal melakukan penelitian implementasi experiential learning dalam proses mencari dan peluang yang diukur dalam intensi kewirausahaan mahasiswa dan kerjasama dengan alumni untuk mendapatkan pengalaman mengelola usaha. 


\section{Daftar Rujukan}

Adel, H.M., Mahrous, A.A. and Hammad, R. 2020, "Entrepreneurial marketing strategy, institutional environment, and business performance of SMEs in Egypt", Journal of Entrepreneurship in Emerging Economies, Vol. 12 No. 5, pp. 727-746. https://doi.org/10.1108/JEEE-11-2019-0171

Alqoot, A.R.M. 2021. Professional development of the performance of faculty members in the field of dealing with entrepreneurship distance learning platforms in light of the corona pandemic (Covid-19). Journal of Entrepreneurship Education, 24(3). Volume 24, Issue 3, 2021

Anthony, S.D. 2014. The first mile: A launch manual for getting great ideas into the market. Harvard Business Review Press.

Aulet, B. 2013. Disciplined entrepreneurship: 24 steps to a successful start-up. John Wiley \& Sons.

Corbett, A. 2005. Experiential learning within the process of opportunity identification and exploitation. Entrepreneurship Theory and Practice, 29(4), 473-491.

Dernti, Michel. 2011. Web Templates as Visual Specifications of Blended Learning Support. Department of Computer Science and Business Informatics. Vienna University, Australia. Download 21Maret 2011. Sources http://www.pdfstock.com/web-templates-as-visual-specifications-of-blended-learningsupport-pdf.html

Esfandiar, K., Sharifi-Tehrani, M., Pratt, S. \& Altinay, L. (2017). Understanding entrepreneurial intentions: A developed integrated structural model approach. Journal of Business Research.

Fayolle, A., Gailly, B. \& Lassas-Clerc, N. 2006. Assessing the impact of entrepreneurship education programmes: A new methodology. Journal of European Industrial Training, 30(9), 701-720.

Garba, M Musa and Shamsu Lawan Abubakar. 2019, Open Journal of Business and Management, 7, 12441261 http://www.scirp.org/journal/ojbm ISSN Online: 2329-3292 ISSN Print: 2329-3284 DOI: 10.4236/ojbm.2019.73087 Jul. 12, 20191244 The Influence of Entrepreneurial Learning Environment and Intrinsic Learners' Need on Entrepreneurship Education

Gay, L. R., Geoffrey E. Mills, And Peter Airasian.2008. Educational Research: Competencies For Analysis And Applications. Upper Saddle River: Pearson Education, Inc., 2008.

Handayati, P; Dwi Wulandari; Budi E.S; A.Wibowo dan B.S, Narmaditya, 2020, Does enytepreneurship education Promote vocational students. Heliyon. Journal Homepage:www.cell.com/heliyon

Išoraitė, M., Gulevičiūtė, G. 2021. A Study of Entrepreneurship Education in Internet Space in Pandemic Conditions, Entrepreneurship and Sustainability Issues, 8(3), 179-192. http://doi.org/10.9770/jesi.2021.8.3(10)

Liguori, Eric and Christoph W., 2020, From Offline to Online: Challenges and Opportunities for Entrepreneurship Education Following the COVID-19 Pandemic. Entrepreneurship Education and Pedagogy, Vol. 3(4) 346-351 Article reuse guidelines: sagepub.com/journals-permissions DOI: $10.1177 / 2515127420916738$ journals.sagepub.com/home/eex

Ogundele, OJK, Akingbade D.A; dan Akinlabi, HB ,2012. 'Entrepreneurship Training And Education as Strategic Tools For Poverty Alleviation In Nigeria', American International Journal of Contemporary Research Vol. 2 No. 1; January 2012

Rasmussen, Einar ,2011.Understanding academic entrepreneurship: Exploring the emergence of university spin-off ventures using process theories International Small Business Journal. 29: 448. SAGE Publication

Ratten, Vanessa ,2020. Coronavirus (covid-19) and entrepreneurship: changing life and work landscape. Journal of Small Business \& Entrepreneurship Volume 32, 2020 - Issue 5. Pages 503-516| Received 29 Jun 2020, Accepted 30 Jun 2020, Published online: 21 Jul 2020 Download citation, https://doi.org/10.1080/08276331.2020.1790167

Secundo G , P. Rippa, and Michele Meoli, 2020, Digital transformation in entrepreneurship education centres: preliminary evidence from the Italian Contamination Labs network. International Journal of Entrepreneurial Behavior \& Research Vol. 26 No. 7, 2020 pp. 1589-1605 Emerald Publishing Limited 1355-2554 DOI 10.1108/IJEBR-11-2019-0618

Suharsono, Naswan , 2018. Pendidikan Kewirausahaan. Dari Teori ke Aplikasi. Tangerang: Penerbit Raja Grafindo

Suharsono, Naswan dan Parma, I Putu Gede, 2020. Post-Pandemic Web-Based Product Marketing: Developing Micro and Small Enterprise Culture. Proceedings of the 5th International Conference on Tourism, Economics, Accounting, Management and Social Science (TEAMS 2020). Advances in Economics, Business and Management Research, Volume 158. https://doi.org/10.2991/ aebmr.k.201212.044 